\title{
Clay minerals in cave sediments and terra rossa soils in the Montagnola Senese karst massif (Italy)
}

\author{
Francesco IACOVIELLO ${ }^{1, *}$ and Ivan MARTINI ${ }^{1}$
}

1 Dipartimento di Scienze Fisiche, della Terra e dell'Ambiente, Università di Siena, via Laterina 8, 53100 Siena, Italy

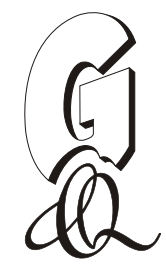

lacoviello F. and Martini I. (2013) Clay minerals in cave sediments and terra rossa soils in the Montagnola Senese karst massif (Italy). Geological Quarterly, 57 (3): 527-536, doi: 10.7306/gq.1111

\begin{abstract}
Reddish mud-rich sediments are common in several karst areas, in the form of red surface soils and clastic cave infillings. The origin and significance of red surface soils have been much debated over recent years, while clastic mud-rich sediments in cave environments have received less attention from geoscientists. The genetic relationship between these two materials still remains uncertain. Because these sediments are mainly composed of fine-grained materials, their study has been generally focused on the clay fraction only. This paper compares the clay fraction of red surface soils and mud-rich cave sediments in the Montagnola Senese karst massif. Previous studies have demonstrated that, in this area, red cave muds originate from the erosion of the similarly red surface soils, that were subsequently re-deposited in the cave environment. Despite these well-established genetic relations, notable differences in the clay fraction of these two materials have been recognized in the present study. These differences are likely to be attributable to the different grades of pedogenetic weathering that affected the two materials. This study demonstrates that the genetic relationship between mud-rich cave sediments and red surface soils can be misinterpreted when only the clay mineral fraction is considered.
\end{abstract}

Key words: cave sediments, terra rossa, clay minerals, red mud, Montagnola Senese.

\section{INTRODUCTION}

Karst terrains are often associated with peculiar reddish and clayey soils commonly known as terra rossa in the literature (see Durn, 2003; Merino and Banerjee, 2008; Muhs et al., 2010 for a general review). These soils are particularly common and well-developed in regions characterized by a Mediterranean climate, such as the Montagnola Senese area investigated in the present work.

The processes responsible for the formation of these peculiar soils have been debated for a long time and traditionally encompass two major theories: of "residual" and "detrital" origins. The "residual" origin hypothesis argues that the clay fraction of these soils results from accumulation of the insoluble residue of the limestone (Reifenberg, 1947; Dudal et al., 1966; Moresi and Mongelli, 1988). Several studies have recently demonstrated that these soils display specific mineralogical and compositional features that cannot be easily explained by the "residual" theory quoted above (Ruhe et al., 1961; Ruhe, 1975; Comer, 1976; Mee et al., 2004; Schaetzl and Anderson, 2005). Thus the "detrital" theory was developed, considering red soils as formed by the accumulation and pedogenetic alteration of alluvial mud, volcanic ash and/or aeolian dust settled on the limestone surface (Yaalon and Ganor, 1973; Jackson et al., 1982;

\footnotetext{
*Corresponding author, e-mail: iacoviello3@unisi.it
}

Received: December 19, 2012; accepted June 4, 2013; first published online: July 5, 2013
Muhs et al., 2010). Other authors take into account the possibility of a polygenetic nature of these soils, invoking the mixing of the insoluble residue of carbonates with other parent materials (Yaalon, 1997; Durn et al., 1999). A similar origin has been suggested for red soils in the Montagnola Senese district (Costantini and Damiani, 2004; Priori et al., 2008; Costantini et al., 2009).

Red clay-rich sediments are also widespread in many cave environments, where they may cover cave floors and walls as thin mud drapes and/or they may form thick sedimentary successions. Their origin and their relation with surface red soils have been investigated by several authors (Bull, 1981; Foos et al., 2000; Lynch et al., 2003; Bosch and White, 2004; Fornós et al., 2009; Martín-Pérez et al., 2010; Martín-García et al., 2011; lacoviello and Martini, 2012), who came to different conclusions regarding their origin.

The extremely high concentration of clay minerals present both in surface red soils and in cave sediments suggests that the investigation of the clay fraction may provide valuable clues to the understanding of the genetic relations between cave sediments and soils. Montagnola Senese is a good natural laboratory to test this possible connection because, at this locality, both the origin of reddish surface soils and also the origin and provenance of the reddish muddy cave sediments are relatively well-known (Costantini and Damiani, 2004; Priori et al., 2008; Costantini et al., 2009; lacoviello and Martini, 2012). This study is based on the X-ray diffraction (XRD) investigation of the clay fraction of these deposits and is aimed at the understanding of their mineralogical similarities and differences, in order to provide a case-study whose basic concepts can be adopted in similar settings. 


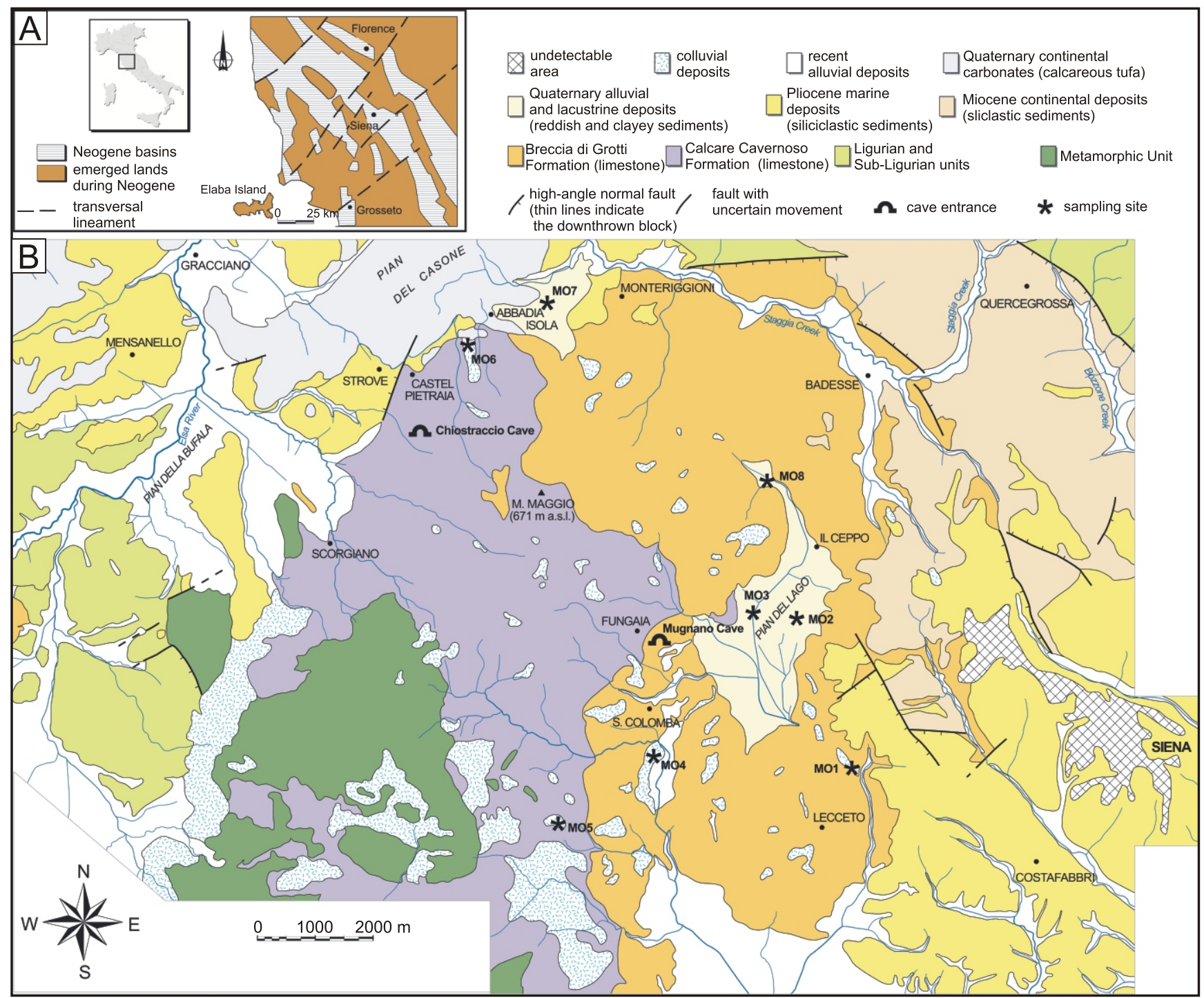

Fig. 1A - geographic location and tectonic sketch of the Inner Northern Apennines; B - simplified geological map of the Montagnola Senese karst massif with location of the collected samples

\section{GEOLOGICAL OUTLINE}

The Montagnola Senese (Fig. 1) corresponds to a series of $\mathrm{N}-\mathrm{S}$ aligned hills west of Siena (Tuscany, Italy), the highest point of which is $671 \mathrm{~m}$ a.s.l. (Monte Maggio). From a geological point of view, the Montagnola Senese is included in the Inner Northern Apennines, a fold-thrust chain formed during the Neogene in response to the interaction between the Adria and Corso-Sardinian microplates (Carmignani et al., 2001 and references therein).

The structural setting of the Northern Apennines is the result of a complex compressional-extensional cycle that started in the Cretaceous and persisted until Quaternary times (Carmignani et al., 1995 and reference therein). The collisional phase was related to the convergence between Europe and the Adria. The extensional post-collisional phase started in the Early-Middle Miocene with the development of low-angle normal faults (Carmignani and Kligfield, 1990; Jolivet et al., 1991; Elter and Sandrelli, 1994), which caused a crustal stretching of $120 \%$ or more (Carmignani and Kligfield, 1990). The extensional regime persisted up to recent times (Early Pliocene to Quaternary) resulting in the development of high-angle nor- mal and transtensional faults, that caused a less substantial stretching (about 10\%) but that strongly influenced the present-day morphological settings of the Inner Northern Appennines (i.e., the "horst and graben" structure, Carmignani et al., 2001; Brogi, 2003).

As a consequence of this complex geological history, the Montagnola Senese corresponds to a morpho-structural high, bounded by tectonic depressions characterized by continental and marine siliciclastic sedimentation in Late Miocene to Pliocene times (Capezzuoli et al., 2009; Martini et al., 2011 and references therein).

The Montagnola Senese is mostly made up of non-metamorphic rocks (the Calcare Cavernoso and the Breccia di Grotti formations, for the details see the following chapter), while metamorphic terrains crop out in its southern sector (Fig. 1B). The metamorphic rocks are affected by a greenschist facies metamorphism (Giannini and Lazzarotto, 1970) and include both siliciclastic and carbonate lithologies, the latter often affected by karst phenomena. However, the present study focuses only on the subsurface soils and karst phenomena related to the non-metamorphic rocks, and for this reason a detailed description of the metamorphic rocks is not provided here. 
To the south and north, the investigated area is bounded by two plains, Pian del Lago and Pian del Casone, respectively. The former (Fig. 1B) corresponds to a large, closed depression surrounded by non-metamorphic karst terrains (Calcare Cavernoso and Breccia di Grotti formations). It has generally been interpreted as a polje (Pascucci, 2004). A different origin is possible for the Pian del Casone which, according to Capezzuoli et al. (2009) and Capezzuoli and Sandrelli (2004), is interpreted as a portion of a tectonic basin characterized by a palustrine-lacustrine sedimentary environment. Regardless of their origin, these flat areas have been associated with lacustrine settings until after the 18th century when they were drained for agriculture purposes (Pascucci, 2004). As a consequence, these areas hosted alluvial and lacustrine deposits characterized by brown/reddish colours, deposited during the Quaternary (Costantini et al., 2009). Lacustrine slack-water sediments are generally characterized by a large amount of fines (silt- and clay-sized particles) with the uncommon occurrence of sand, granules and pebbles, while alluvial deposits are richer in sand and gravel (with generally rounded clasts). These deposits are obviously related to the erosion of surface red soils and reddish colluvial deposits that are widespread in this area. Colluvial deposits are characterized by a high percentage of angular and sub-angular limestone debris, which indicates only short-distance transport and negligible reworking of the original parent rock. However, colluvial deposits are also rich in fines and are characterized by a general lack of sand- sized particles. During the Quaternary, the low-lying area of Pian del Casone locally hosted a continental carbonate depositional environments with lacustrine limestones and calcareous tufa deposits (Capezzuoli et al., 2009).

\section{KARST PHENOMENA}

The non-metamorphic bedrock in this sector of the Montagnola Senese area is composed of two different types of limestone: the Calcare Cavernoso and the Breccia di Grotti formations. These are two genetically related formations because the Breccia di Grotti Formation is composed of continental breccias and sandstones, almost exclusively represented by Calcare Cavernoso derived elements, deposited during the Neogene in an alluvial fan setting (Signorini, 1966; Giannini and Lazzarotto, 1970). The Calcare Cavernoso Formation consists of clast- to matrix-supported dolomitic limestone with a characteristic vacuolar texture (Passeri, 1975, 1979; Gandin et al., 2000; Lugli, 2001; Lugli et al., 2002; Martini 2011). This formation was formed during the Neogene as a consequence of the dissolution of sulphates and destabilization of a Triassic brecciated dolostone, known as the Anidriti di Burano Formation in the literature (Gandin et al., 2000). A peculiar lithofacies of this formation is the so-called Cenerone (Passeri, 1975): it is made up of dark grey, powdery or sandy dolomite that forms masses or lenses characterized by a poor degree of cohesion (Gandin et al., 2000; Lugli, 2001). The origin of this lithofacies is attributable to weathering that affected the remnants of the original dolomitic clasts (Gandin et al., 2000; Lugli, 2001).

As mentioned above, the Calcare Cavernoso Fm. is a dolomitic limestone with only traces of other minerals. Gandin et al. (2000) reported accessory quartz, albite, iron oxides and muscovite-chlorite phyllosilicates. Iacoviello and Martini (2012) performed an acid dissolution (1 M Sodium Acetate solution buffered at $\mathrm{pH} 5$ with Acetic Acid) on crushed limestone samples that allowed the identification of clay minerals, feldspar and scarce tourmaline, iron oxides and quartz.
Karst phenomena strongly affect both the Calcare Cavernoso and the Breccia di Grotti formations (Martini, 2011). The main expression of surface karst phenomena is represented by the Pian del Lago polje and by the many dolines widespread across this area. Furthermore, various types of karren characterize the landscape where the limestone is not covered/protected by soils. Hypogean phenomena include more than 80 caves, generally small in extension and in depth. Caves are generally developed along joints and fractures, often recognizable on the land surface as local depressions.

\section{MATERIALS AND METHODS}

Eight soil samples have been collected with a manual corer at the standard depth of $60 \mathrm{~cm}$ below the land surface in order to avoid anthropogenic influence. Cave sediments were collected by manual picking, in a vertical exposure inside the Mugnano Cave (see Fig. 1B for geographic location).

X-ray diffraction (XRD) analyses were performed on the clay fraction of each sample. XRD measurements were conducted with an automated Philips PW1710 Bragg-Brentano diffractometer, using CuK $\alpha$ radiation $(40 \mathrm{kV}, 20 \mathrm{~mA} \lambda=$ $1.5418 \AA$ ). . Diffractograms were processed using the "MacDiff" software (Petschick, 2001). The clay mineral assemblage was determined using texturally oriented samples. The clay fraction $(<2 \mu \mathrm{m})$ was isolated in settling tubes by gravity sedimentation. Clay samples were spread on glass slides and slowly dried to allow a horizontal orientation of the phyllosilicates. XRD patterns of oriented samples were taken after the following treatments: air drying, glycol solvation, K-saturation and heating to $550^{\circ} \mathrm{C}$ for one hour. The samples were $\mathrm{X}$-rayed in the range $4-40^{\circ} 2 \theta$ with a step size of $0.02^{\circ} 2 \theta$ and a measuring time of 2 $\mathrm{s} /$ step. Additionally, the range $27.5-30.6^{\circ} 2 \theta$ was measured with a step size of $0.01^{\circ} 2 \theta$ and a measuring time of $4 \mathrm{~s} / \mathrm{step}$ in order to better resolve the peaks of kaolinite and chlorite (Biscaye, 1965). XRD identification criteria were based on the indications of Biscaye (1965), Brindley and Brown (1980), Wilson (1987), Barnhisel and Bertsch (1989), and Moore and Reynolds (1997). Clay minerals founded in the examined samples were: illite, smectite, vermiculite, mixed layer mica-vermiculite (ML I/V) and kaolinite. The term "illite" is used here according to the definition proposed by Grim et al. (1937). Semi-quantitative mineral estimation of the clay minerals was based on the procedure described by Gjems (1967), using the peak area and the correction factors (coefficient of proportionality, "C") of diagnostic peaks for each clay mineral:

illite: peak area $\approx 10 \AA ;$ C $=1$;

smectite: peak area $\approx 16.5 \AA ; C=0.23$;

vermiculite: peak area $\approx 14 \AA ; C=0.34$;

kaolinite: peak area $\approx 7 \AA ; C=0.24$;

mixed layer $(M L I / N)$ : peak area $\approx 12 \AA, C=0.40$.

Bulk chemical analyses were obtained by $X$-ray fluorescence (XRF). For XRF, samples have been mechanically crushed in a planetary ball mill and manually ground into powder in an agate mortar. Quantitative analyses were performed on powder discs obtained by pressing $7 \mathrm{~g}$ of sample on a boric acid pellet. The XRF apparatus was a Philips MagicX-Pro. Background and mass absorption intensities were calculated using calibrations based on 24 international geological reference materials. Loss on ignition was determined by heating samples to $1050^{\circ} \mathrm{C}$ for two hours. 


\section{CLAY MINERALS ON CAVE SEDIMENTS}

A previous study on the cave sediments analysed in the present work was recently published by lacoviello and Martini (2012). That study, based on an integrated sedimentological, XRD and SEM approach, showed that all these sediments were mainly derived from an allochthonous source (i.e., external to the cave). Only a few samples displayed a peculiar mineralogical composition indicating a mixture of autochthonous and allochthonous materials. In this study, only those samples displaying pure allochthonous compositions were taken into account. A summary of the main features of the analysed samples are given in Table 1. Two broad categories of cave sediments can been distinguished on the basis of average grain-size: (1) mud-dominated (MU3, MU5-10, MU12-14), and (2) sand-dominated (with an abundant silty/clayey matrix, samples: MU1, MU2, MU4, MU11) sediments. In all the samples, the muddy fraction shows a typical reddish colour (Fig. 2).

The fourteen investigated sediments show a substantial homogeneity regarding mineralogical composition and the relative abundance of each phase (Fig. 3). Three clay minerals were identified: illite is the most abundant $(77-89 \%)$, followed in abundance by kaolinite (10-22\%) and vermiculite (traces to $2 \%$ ). Average contents for illite, kaolinite and vermiculite are
Lithology and Munsell ${ }^{\circledR}$ colour (wet and dry) of the investigated cave sediments (modified after lacoviello and Martini, 2012)

\begin{tabular}{|l|c|l|l|l|l|}
\hline \multirow{2}{*}{ Sample } & \multirow{2}{*}{$\begin{array}{c}\text { Lithol- } \\
\text { ogy }\end{array}$} & \multicolumn{4}{|c|}{ Munsell $^{\circledR}$ color } \\
\cline { 3 - 6 } & mud & 2.5 YR & $4 / 6$ & 5 YR & $5 / 8$ \\
\hline MU14 & met & dry \\
\hline MU13 & mud & 2.5 YR & $4 / 8$ & 5 YR & $6 / 8$ \\
\hline MU12 & mud & 2.5 YR & $4 / 6$ & 5 YR & $6 / 8$ \\
\hline MU11 & sand & 5 YR & $5 / 4$ & 5 YR & $7 / 6$ \\
\hline MU10 & mud & 2.5 YR & $4 / 6$ & 5 YR & $6 / 8$ \\
\hline MU9 & mud & 2.5 YR & $4 / 8$ & 5 YR & $5 / 6$ \\
\hline MU8 & mud & 2.5 YR & $4 / 8$ & 5 YR & $5 / 6$ \\
\hline MU7 & mud & 2.5 YR & $3 / 6$ & 5 YR & $6 / 8$ \\
\hline MU6 & mud & 2.5 YR & $3 / 6$ & 5 YR & $6 / 6$ \\
\hline MU5 & mud & 2.5 YR & $4 / 6$ & 5 YR & $6 / 8$ \\
\hline MU4 & sand & 2.5 YR & $3 / 4$ & 5 YR & $5 / 6$ \\
\hline MU3 & mud & 2.5 YR & $4 / 6$ & 5 YR & $6 / 6$ \\
\hline MU2 & sand & 2.5 YR & $3 / 4$ & 5 YR & $6 / 8$ \\
\hline MU1 & sand & 2.5 YR & $3 / 6$ & 5 YR & $7 / 6$ \\
\hline
\end{tabular}
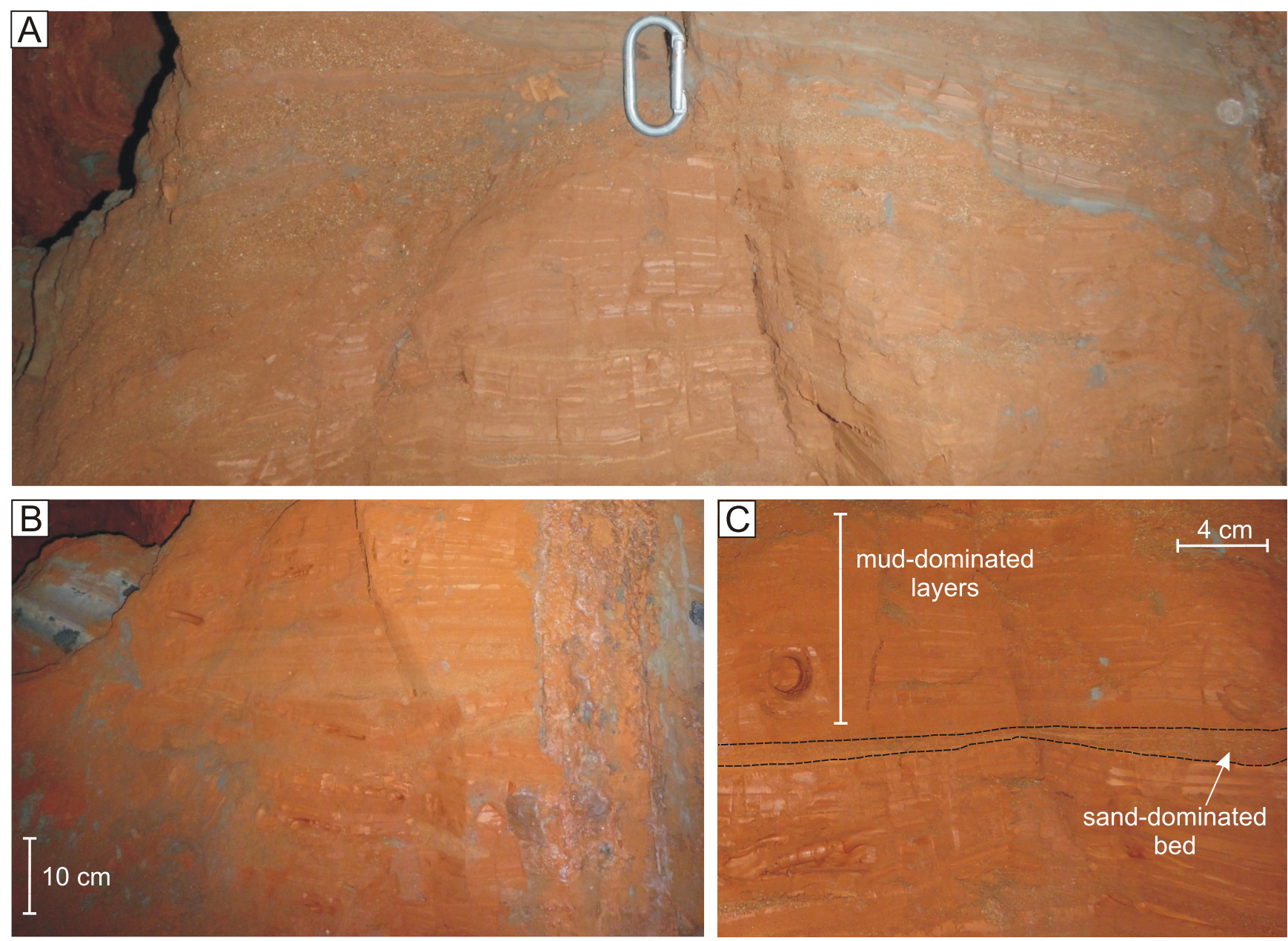

Fig. 2. Red sediments inside the Mugnano Cave

A - cave sediments in a vertical exposure, carabiner for scale is about $10 \mathrm{~cm}$ long; B - alternation of mud-dominated and sand-dominated beds; C - close-up view of the relation between mud-dominated sediments and a sand layer 


\section{CAVE SEDIMENTS}
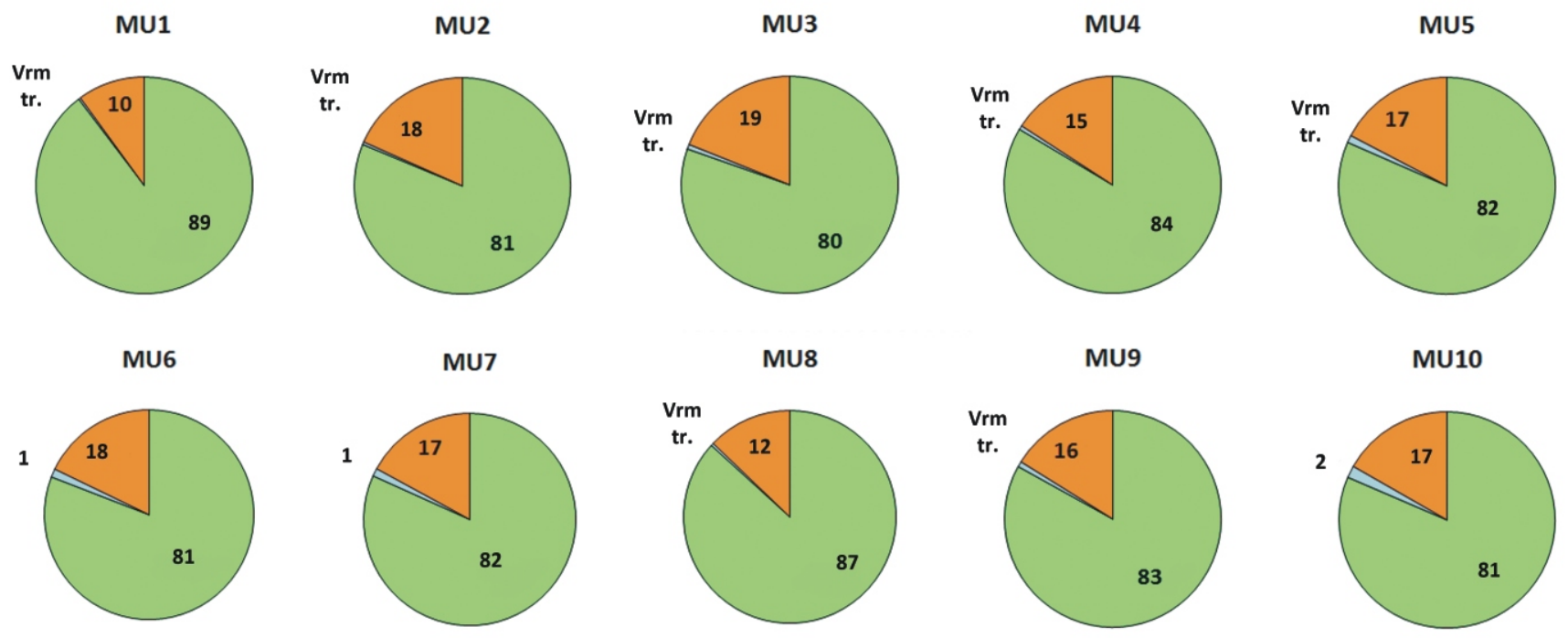

MU11

MU12

MU13

MU14
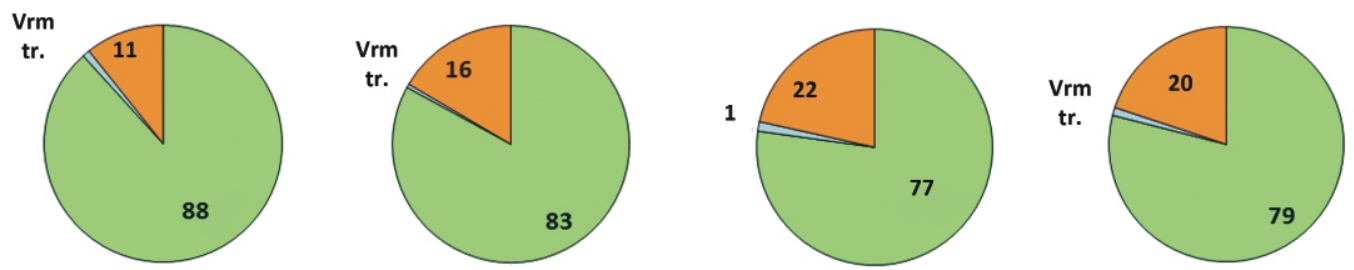

\section{RED SOILS}
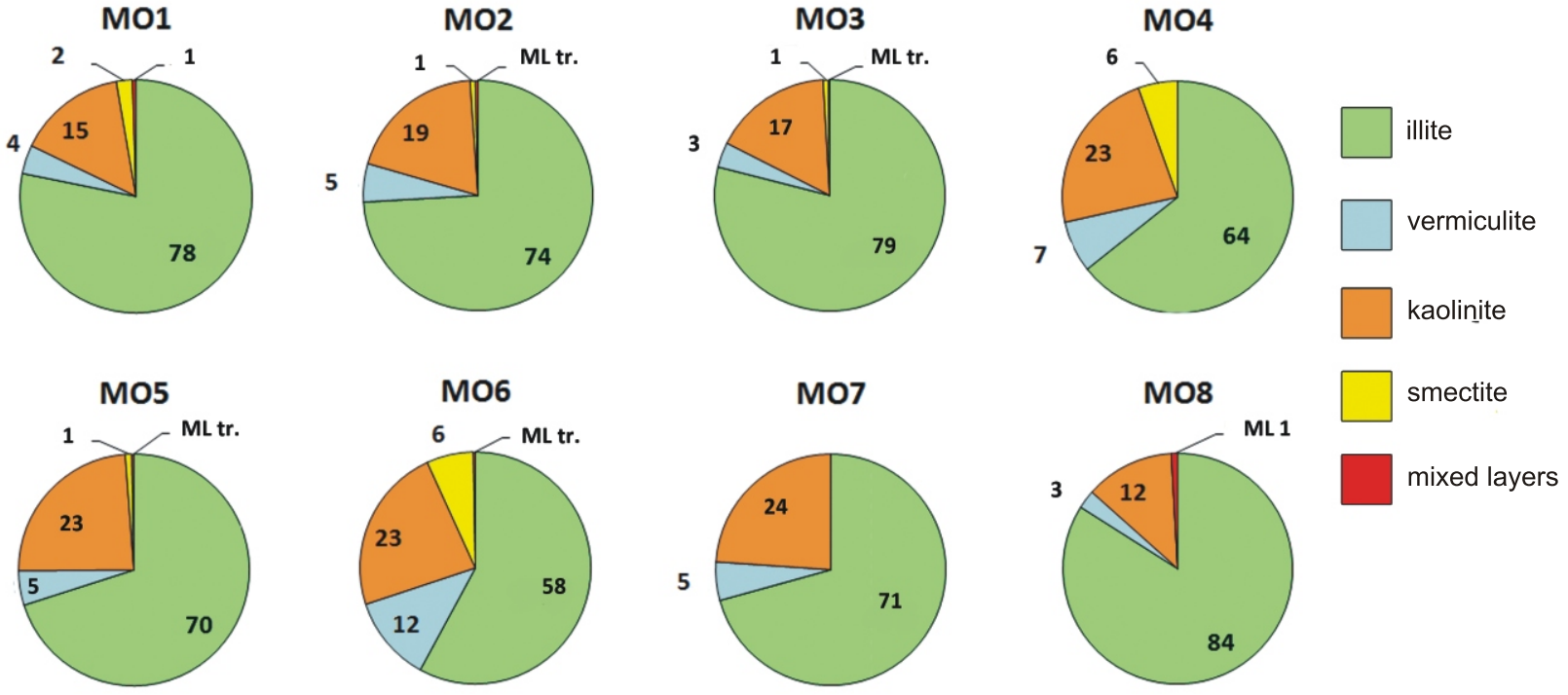

Fig. 3. Semi-quantitative compositional analysis of the clay fraction of the cave sediments and of the surface red soils $\mathrm{ML}$ - mixed layers, tr. - traces indicates percentages less than $1 \%, \mathrm{Vrm}-$ vermiculite 
83,16 and about $1 \%$, respectively. Samples MU1, MU8 and MU11 show relatively lower amounts of kaolinite with higher illite contents. Samples MU13 and MU14 have the highest kaolinite contents (22 and $20 \%$, respectively). No significant differences could be identified between mud- and sand-dominated sediments.

\section{CLAY MINERALS OF THE TERRA ROSSA SOILS}

Terra rossa soils are widespread in the investigated area and due to their occurrence in topographic depressions they are often used for agriculture purposes (Fig. 4). A synthesis of the main features of the samples analysed is reported in Table 2, while their bulk chemical composition is reported in Table 3 .
Five clay minerals were identified (Fig. 3): illite is the most abundant, and shows rather large oscillations (58-84\%), followed by kaolinite (12-24\%), vermiculite (3-12\%), smectite $(0-6 \%)$ and mixed layer minerals (traces to $1 \%)$. The average illite content is $72 \%$, while lower values were observed in samples MO4 and MO6, (64 and 58\%, respectively); these two samples also display relatively higher percentages of smectite $(6 \%)$, as well as relatively higher vermiculite contents (7 and $12 \%$, respectively). These values are considerably higher than the average percentages of both smectite $(2 \%)$ and vermiculite (5.5\%).

Mixed layer minerals are present in traces. Only sample MO8 displays detectable amounts (1\%) of mixed layer minerals.
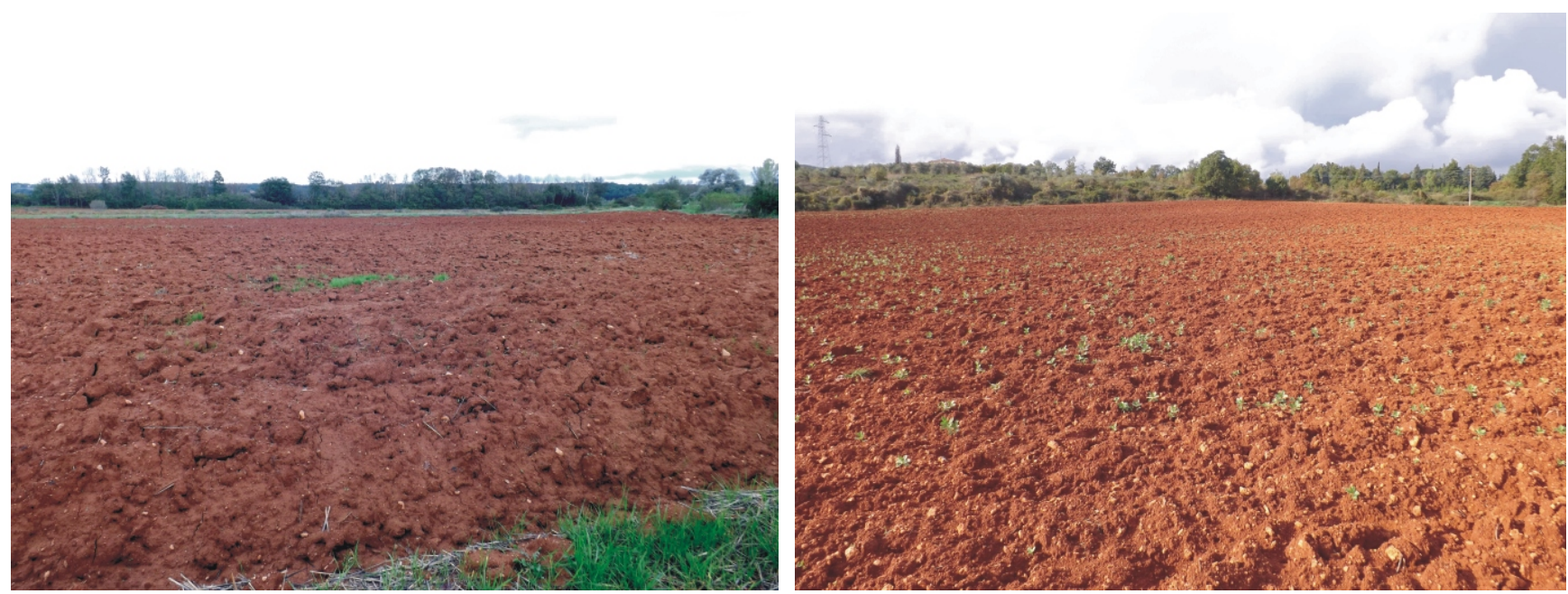

Fig. 4. Typical aspects of surface red soils in agricultural use

Table 2

Main features of the investigated soil samples with UTM coordinates (datum WGS84, zone 32) and elevations

\begin{tabular}{|c|c|c|c|c|c|c|c|c|c|}
\hline \multirow{3}{*}{$\begin{array}{l}\text { Sample } \\
\text { MO1 }\end{array}$} & \multirow{3}{*}{$\begin{array}{c}\text { UTM } \\
\text { Nord } \\
4798642\end{array}$} & \multirow{3}{*}{$\begin{array}{c}\text { UTM } \\
\text { East } \\
0684158\end{array}$} & \multirow{3}{*}{$\begin{array}{c}\begin{array}{c}\text { Elevation } \\
\text { [m a.s.I.] }\end{array} \\
274\end{array}$} & \multirow{3}{*}{$\begin{array}{c}\text { Depositional } \\
\text { environment }\end{array}$} & \multicolumn{4}{|c|}{ Munsell $^{\circledR}$ color } & \multirow{3}{*}{$\begin{array}{c}\text { Skeletal grains } \\
\begin{array}{c}\text { sand with uncom- } \\
\text { mon subrounded } \\
\text { gravels }\end{array}\end{array}$} \\
\hline & & & & & \multicolumn{2}{|c|}{ wet } & \multicolumn{2}{|c|}{ dry } & \\
\hline & & & & & $5 \mathrm{YR}$ & $4 / 3$ & $10 \mathrm{YR}$ & $5 / 4$ & \\
\hline MO2 & 4801189 & 0683083 & 261 & lacustrine & 7.5 YR & $4 / 4$ & $10 \mathrm{YR}$ & $5 / 6$ & $\begin{array}{l}\text { sand with } \\
\text { subrounded/rounded } \\
\text { small gravels }\end{array}$ \\
\hline MO3 & 4800947 & 0682288 & 259 & lacustrine & $7.5 \mathrm{YR}$ & $3 / 3$ & 7.5 YR & $5 / 4$ & scarce sand \\
\hline MO4 & 4799110 & 0681079 & 313 & colluvial & $2.5 \mathrm{YR}$ & $5 / 4$ & $5 \mathrm{YR}$ & $4 / 4$ & $\begin{array}{c}\text { angular/subangular } \\
\text { limestone debris }\end{array}$ \\
\hline MO5 & 4798233 & 0678137 & 475 & colluvial & $2.5 \mathrm{YR}$ & $3 / 4$ & $7.5 \mathrm{YR}$ & $4 / 4$ & $\begin{array}{l}\text { scarce subangular } \\
\text { limestone debris }\end{array}$ \\
\hline MO6 & 4805759 & 0676950 & 281 & alluvial/colluvial & $2.5 \mathrm{YR}$ & $4 / 4$ & $10 \mathrm{YR}$ & $5 / 4$ & $\begin{array}{c}\text { subangular and } \\
\text { alterated limestone } \\
\text { debris }\end{array}$ \\
\hline MO7 & 4806354 & 0677924 & 200 & lacustrine & 7.5 YR & $4 / 3$ & $10 \mathrm{YR}$ & $5 / 4$ & $\begin{array}{l}\text { scarce subangular } \\
\text { limestone debris }\end{array}$ \\
\hline MO8 & 4803845 & 0682644 & 283 & lacustrine & $5 \mathrm{YR}$ & $4 / 4$ & 7.5 YR & $4 / 6$ & $\begin{array}{l}\text { subangular to } \\
\text { subrounded and } \\
\text { unalterated lime- } \\
\text { stone debris }\end{array}$ \\
\hline
\end{tabular}


Chemical results obtained by XRF (X-ray fluorescence) for the collected soil samples

\begin{tabular}{|c|c|c|c|c|c|c|c|c|c|}
\hline & & MO1 & MO2 & MO3 & MO4 & MO5 & MO6 & MO7 & MO8 \\
\hline $\mathrm{Na}_{2} \mathrm{O}$ & [\%] & 0.68 & 0.55 & 0.68 & 0.45 & 0.41 & 0.45 & 0.62 & 0.53 \\
\hline $\mathrm{MgO}$ & [\%] & 2.33 & 1.48 & 2.05 & 2.86 & 2.43 & 1.38 & 2.13 & 2.67 \\
\hline $\mathrm{Al}_{2} \mathrm{O}_{3}$ & [\%] & 18.99 & 17.61 & 17.25 & 19.47 & 19.21 & 17.18 & 18.12 & 17.80 \\
\hline $\mathrm{SiO}_{2}$ & [\%] & 67.26 & 70.42 & 67.22 & 40.57 & 46.41 & 65.51 & 51.86 & 54.98 \\
\hline $\mathrm{P}_{2} \mathrm{O}_{5}$ & [\%] & 0.07 & 0.04 & 0.09 & 0.11 & 0.09 & 0.10 & 0.19 & 0.10 \\
\hline $\mathrm{K}_{2} \mathrm{O}$ & [\%] & 0.91 & 0.49 & 0.87 & 2.05 & 1.92 & 1.52 & 1.58 & 1.75 \\
\hline $\mathrm{CaO}$ & [\%] & 0.80 & 0.20 & 0.99 & 5.28 & 1.36 & 1.34 & 5.67 & 5.93 \\
\hline $\mathrm{TiO}_{2}$ & [\%] & 0.23 & 0.17 & 0.45 & 0.59 & 0.62 & 0.64 & 0.53 & 0.57 \\
\hline $\mathrm{MnO}$ & [\%] & 0.06 & 0.06 & 0.06 & 0.07 & 0.13 & 0.11 & 0.06 & 0.07 \\
\hline $\mathrm{Fe}_{2} \mathrm{O}_{3}$ & [\%] & 2.10 & 2.49 & 3.05 & 14.05 & 16.68 & 4.92 & 4.52 & 3.73 \\
\hline L.O.I. & [\%] & 6.52 & 6.41 & 7.28 & 14.40 & 10.60 & 6.76 & 14.60 & 11.80 \\
\hline $\mathrm{Nb}$ & [ppm] & 13 & 7 & 8 & 15 & 21 & 18 & 17 & 15 \\
\hline $\mathrm{Zr}$ & [ppm] & 134 & 169 & 170 & 194 & 360 & 303 & 332 & 207 \\
\hline$Y$ & [ppm] & 2 & 10 & 8 & 20 & 11 & 2 & 13 & 14 \\
\hline $\mathrm{Sr}$ & [ppm] & 12 & 41 & 62 & 13 & 13 & 8 & 62 & 57 \\
\hline $\mathrm{Rb}$ & [ppm] & 52 & 51 & 58 & 98 & 110 & 65 & 94 & 63 \\
\hline $\mathrm{Ni}$ & [ppm] & 0 & $<1$ & 2 & 63 & 78 & 44 & 52 & 34 \\
\hline $\mathrm{Cr}$ & [ppm] & 49 & 44 & 6 & 64 & 73 & 108 & 84 & 74 \\
\hline V & [ppm] & 20 & 24 & 22 & 60 & 67 & 44 & 40 & 39 \\
\hline $\mathrm{Ba}$ & [ppm] & 583 & 356 & 425 & 385 & 548 & 491 & 473 & 422 \\
\hline $\mathrm{La}$ & [ppm] & 5 & 10 & 8 & 14 & 20 & 14 & 16 & 8 \\
\hline $\mathrm{Ce}$ & [ppm] & 8 & 19 & 14 & $<1$ & $<1$ & 26 & 31 & 14 \\
\hline $\mathrm{Pb}$ & [ppm] & 15 & 19 & 20 & 43 & 36 & 31 & 37 & 15 \\
\hline Co & [ppm] & 37 & 61 & 58 & 90 & 103 & 2 & 2 & 4 \\
\hline Th & [ppm] & 2 & 5 & 4 & 7 & 12 & 6 & 9 & 5 \\
\hline $\mathrm{U}$ & [ppm] & 2 & 2 & 3 & 1 & 1 & 1 & 2 & 2 \\
\hline $\mathrm{Zn}$ & (ppm] & 23 & 18 & 32 & 62 & 54 & 33 & 46 & 33 \\
\hline $\mathrm{Ti} / \mathrm{Zr}$ & & 10.1 & 5.9 & 15.9 & 18.2 & 10.3 & 12.7 & 9.6 & 16.4 \\
\hline
\end{tabular}

L.O.I. - loss on ignition

\section{DISCUSSION}

The studies previously performed on these cave sediments demonstrated that their origin is strongly related to the arrival of sediment-laden flows (i.e., sediment-rich flows with high suspended sediment concentrations) from the overlying and surrounding landscape to the internal part of the cave. This conclusion is supported by a range of evidence, such as the mineralogical and sedimentological features that characterize the cave sediments, and the occurrence of gastropod remains, as gasteropods are unable to live in a cave environment (see lacoviello and Martini, 2012 for more detailed description). As a consequence, the most realistic source of cave-sediments was the erosion of surface soils widespread in this area.

Despite the genetic relationships established between cave sediments and red surface soils, notable differences in the clay mineralogy of these two families of materials are easily recognizable. Red surface-soil samples display high vermiculite contents $(3-12 \%)$ in contrast to the generally low values in cave-sediments (traces to $2 \%$ ). Furthermore, red soil samples contain smectite and mixed layer clays, that were not detected in cave-samples. Kaolinite is abundant in all the samples investigated, although its average value in red soil samples (20\%) is a little higher than the average kaolinite content in cave-sediments $(16 \%)$. Illite is the most abundant clay mineral phase even though soil samples display generally lower percentages of this mineral.

The different composition could be explained in various ways, but the data suggest that they are due to pedogenetic processes that have affected surface soils in recent times, while cave-sediments, once deposited, were left unchanged. In fact, a typical pedogenic evolution consists of the alteration of illite with the formation of vermiculite, smectitic mixed layers, smectite, kaolinite and amorphous compounds (Millot, 1970; Jackson, 1964; Chamley, 1989). However, kaolinite is reported as a primary constituent of the limestone bedrock cropping out in the Montagnola Senese (Gandin et al., 2000; lacoviello and Martini, 2012) and for this reason its occurrence in the cave-sediments does not provide any information about the degree pedogenetic weathering. By contrast, vermiculite can be considered as a reliable marker of pedogenesis, and there is general agreement that most vermiculites are derived by the weathering of mica and illite (Walker, 1949; Barnhisel and Bertsch, 1989; Douglas, 1989). A similar statement may be made regarding mixed layer clay minerals (Sawhney, 1989) and for smectite, because the two phases were not detected in the bedrock insoluble residue (Gandin et al. 2000; lacoviello and Martini, 2012). However, the formation of smectite is strongly influenced by topographic and local conditions (Borchardt, 1989), which prevent or strongly limit the significance of the smectite as a marker for understanding the degree of pedogenesis affecting the soils. 
With regard to the red soils in the Montagnola Senese area, Costantini et al. (2009) demonstrated that these have a polygenetic origin (e.g., aeolian deposits of various nature, pedogenically altered and mixed with the underlying sediments). These authors based their conclusions on a range of geological, pedological and geochemical evidence, including the $\mathrm{Ti} / \mathrm{Zr}$ ratio that generally helps to identify the contribution of aeolian materials to the formation of terra rossa soils (Dickson and Scott, 1998; Tate et al., 2007). The Ti/Zr ratios of the soil samples analysed in the context of this study (Table 3 ) are always low and in line with those reported by Costantini et al. (2009) for the most surficial horizons of the soil profiles. Consequently, a similar polygenetic origin is also possible for the soil samples discussed in the present paper. Costantini et al. (2009) provide also optically stimulated luminescence (OSL) dates that show that older surface-soils and/or soil horizons of the area have developed since at least the Late Pleistocene $(72.6 \pm 9.1 \mathrm{ka})$, and that their development persisted until the present (Costantini et al., 2009, reported that the younger recorded age was $3.33 \pm 0.44 \mathrm{ka}$, suggesting that pedogenetic processes are still active). Therefore, it can be supposed that the erosion of surface soils and their consequent re-deposition in the cave environment have occurred during an earlier stage of pedogenesis, when the alteration processes had not yet resulted in to the deep transformation of illite to alteration products such as vermiculite, mixed layers and smectite. This hypothesis is corroborated by the mineralogical differences of soils samples collected from different areas: samples collected in alluvial and colluvial settings (i.e., samples MO1, MO4-6) generally display higher values of vermiculite and smectite in comparison to those collected from "lacustrine" sediments (i.e., samples MO2, MO3, MO7, MO8). It is important to remember that lacustrine settings persisted until the 18th century when lakes were drained (Pascucci, 2004). Consequently, "red lacustrine deposits" derive from the erosion of surface soils and the re-deposition (and perhaps partial subsequent reoxidation) of sediments in a lacustrine environment. This implies that pedogenetic processes have affected these sediments for a shorter time compared to the alluvial/colluvial ones, because pedogenetic processes cannot operate in subaqueous environments. Hence, deposits that were never subject to lacustrine conditions would display a higher degree of pedogenetic alteration, expressed by an increase in alteration-derived clay minerals.

These observations demonstrate that trying to understand the genetic relations between cave sediments and surface red soils just by analysing their clay mineralogy may be problematic, and sometimes even misleading. This is particularly the case when cave sediments were emplaced during the early stages of pedogenesis, so that their clay-fraction is composed mainly of weakly altered minerals. By contrast, surface soils, having been affected by pedogenesis and weathering for a longer time, may become enriched in alteration-derived mineralogical phases.

\section{CONCLUSIONS}

In this paper the clay minerals of cave sediments and of surface red soils of the Montagnola Senese area have been investigated in order to understand the reason for their similarities and differences. Previous authors have investigated these two categories of sediments separately. Costantini and Damiani (2004), Priori et al. (2008) and Costantini et al. (2009) have studied surface soils, considering their age of formation and the important contribution of aeolian materials to the development of red soils; on the other hand lacoviello and Martini (2012) demonstrated that red mud sediments in caves originated by the erosion and the subsequent re-deposition of surface soils.

Despite these well-documented genetic relations, the data obtained in the present work indicate significant differences in the clay mineral assemblages in surface red soils and cave sediments. In detail, the latter are deficient in vermiculite, smectite and mixed layer clays, compared with surface soils. Moreover, the percentage of these three phases is extremely variable also in surface soil samples: a general enrichment can be recognized in the samples representative of alluvial/colluvial environments (e.g., exposed to pedogenetic processes for a longer time), while lower values were detected in the samples representative of a lacustrine environment (e.g., pedogenetic processes were active only prior to subaqueous deposition). The data suggest that the mineralogical differences between the two materials can be attributed to the different degree of pedogenesis that affected cave sediments and surface red soils. Realistically, the cave sediments investigated might have been emplaced during an early stage of pedogenesis in which the alteration processes had no time to strongly weather the original parent materials.

Finally, these data show that investigation of only the clay-fraction is insufficient, sometimes even misleading, when trying to understand the genetic relation between cave sediments and surface soils. The results of our comparative study suggest that the great differences in the clay mineral assemblages of surface soils and cave sediments of the Montagnola Senese area can be ascribed to differential pedogenetic processes, and they do not indicate a lack of genetic relations between the two.

Acknowledgments. We are grateful to all the members of Commissione Speleologica "I Cavernicoli" (C.A.I. Siena), for their assistance during fieldwork activity and to Dr. A. Frullatori for her help with language. We are grateful to Dr. S. Priori and to Prof. A. Mindszenty for their constructive comments. M. Gradziński is thanked for editorial comments and handling of the manuscript. The research was supported by Banca Monte dei Paschi di Siena S.p.A.

\section{REFERENCES}

Barnhisel R.I., Bertsch P.M. (1989) Chlorites and Hydroxy-Interlayered Vermiculite and Smectite. In: Minerals in Soil Environments (eds. J.B. Dixon and S.B. Weed): 729-788. Soil Science Society of America, Madison, Wisconsin, USA.

Biscaye P.E. (1965) Mineralogy and sedimentation of recent deep-sea clay in the Atlantic Ocean and adjacent seas and oceans. GSA Bulletin, 76: 803-832.
Borchardt G. (1989) Smectites. In: Minerals in Soil Environments (eds. J.B. Dixon and S.B. Weed): 675-727. Soil Science Society of America, Madison, Wisconsin, USA.

Bosch R.F., White W.B. (2004) Lithofacies and transport of clastic sediments in karstic aquifers. In: Studies of Cave Sediments (eds. I.D. Sasowsky and J.E. Mylroie): 1-22. Kluwer Academic/Plenum Publisher, New York. 
Brindley G.W., Brown G. (1980) Crystal structures of clay minerals and their X-ray identification. Mineralogical Society, London.

Brogi A. (2003) Megaboudinage della Falda Toscana nell'area geotermica del M. Amiata e relazioni con la tettonica distensiva miocenica dell'Appennino Settentrionale. Geo Acta, Special Issue, 2: 33-36.

Bull P.A. (1981) Some fine-grained sedimentation phenomena in caves. Earth Surface Processes and Landforms, 6: 11-22.

Capezzuoli E., Sandrelli F. (2004) I sedimenti quaternari del settore meridionale della Valdelsa (Provincia di Siena). Italian Journal of Quaternary Sciences, 17: 33-40.

Capezzuoli E., Priori S., Costantini E.A.C., Sandrelli F. (2009) Stratigraphic and paleopedological aspects from the Middle Pleistocene continental deposits of the southern Valdelsa Basin. Bollettino della Società Geologica Italiana, 128: 395-402.

Carmignani L., Kligfield R. (1990) Crustal extension in the northern Apennines: the transition from compression to extension in the Alpi Apuane core complex. Tectonics, 9: 1275-1303.

Carmignani L., Decandia F.A., Disperati L., Fantozzi P.L., Lazzarotto A., Liotta D., Oggiano G. (1995) Relationships between the Sardinia-Corsica-Provençal Domain and the Northern Apennines. Terra Nova, 7: 128-137.

Carmignani L., Decandia F.A., Disperati L., Fantozzi P.L., Kligfield R., Lazzarotto A., Liotta D., Meccheri M. (2001) Inner Northern Apennines. In: Anatomy of an Orogen: the Appennines and Adjacent Mediterranean Basins (eds. G.B. Vai and I.P. Martini): 197-214. Kluwer Academic/Plenum Publisher, London.

Chamley H. (1989) Clay Sedimentology. Springer-Verlag, Berlin.

Comer J.B. (1976) Genesis of Jamaican bauxite: a reply. Economic Geology, 71: 822-823.

Costantini E.A.C., Damiani D. (2004) Clay minerals and the development of Quaternary soils in central Italy. Revista Mexicana de Ciencias Geológicas, 21: 144-159.

Costantini E.A.C., Priori S., Urban B., Hilgers A., Sauer D., Protano G., Trombino L., Hulle D., Nannoni F. (2009) Multidisciplinary characterization of the middle Holocene eolian deposits of the Elsa River basin (central Italy). Quaternary International, 209: 107-130.

Dickson B.L., Scott K.M. (1998) Recognition of aeolian soils of the Blayney district, NSW: implications for mineral exploration. Journal of Geochemical Exploration, 63: 237-251.

Douglas L.A. (1989) Vermiculites. In: Minerals in Soil Environments (eds. J.B. Dixon and S.B. Weed): 635-674. Soil Science Society of America, Madison, Wisconsin, USA.

Dudal R., Tavernier R., Osmond D. (1966) Soil Map of Europe $(1: 2,500,000)$, with explanatory text (120 p.). Food and Agriculture Organization of the United Nations, Rome.

Durn G. (2003) Terra rossa in the Mediterranean region: parent materials, composition and origin. Geologica Croatica, 56: 83-100.

Durn G., Ottner F., Slovenec D. (1999) Mineralogical and geochemical indicators of the polygenetic nature of terra rossa in Istria, Croatia. Geoderma, 91: 125-150.

Elter F.M., Sandrelli F. (1994) La fase post-nappe nella Toscana meridionale: nuova interpretazione sull'evoluzione dell'Appennino settentrionale. Atti Ticinesi Scienze della Terra, 37: 173-193.

Foos A.M., Sasowsky I.D., LaRock E.J., Kambesis P.N. (2000) Detrital origin of a sedimentary fill, Lechuguilla cave, Guadalupe Mountains, New Mexico. Clays and Clay Minerals, 48 (6): 693-698.

Fornós J.J., Ginés J., GrBcia F. (2009) Present-day sedimentary facies in the coastal karst caves of Mallorca island (western Mediterranean). Journal of Cave and Karst Studies, 71: 86-99.

Gandin A., Giamello M., Guasparri G., Mugnaini S., Sabatini G. (2000) The calcare cavernoso of the Montagnola Senese (Siena, Italy): mineralogical-petrographic and petrogenetic features. Mineralogica et Petrographica Acta, 43: 271-289.

Giannini E., Lazzarotto A. (1970) Studio geologico della Montagnola Senese. Memorie della Società Geologica Italiana, 9: $451-495$.
Gjems O. (1967) Studies on clay minerals and clay-mineral formation in soil profiles in Scandinavia-Norwegian Forest. Vollebekk, Norway, Meddelelser fra det norske skogforsoksvesen (Reports of the Norwegian Forest Research Institute), 21: 303-345.

Grim R.E., Bray R.H., Bradley W.F. (1937) The mica in argillaceous sediments. American Mineralogist, 22: 813-829.

lacoviello F., Martini I. (2012) Provenance and geological significance of red mud and other clastic sediments of the Mugnano Cave (Montagnola Senese, Italy). International Journal of Speleology, 41 (2): 317-328.

Jackson M.L. (1964) Chemical composition of soils. In: Chemistry of the Soil (ed. F.E. Bear): 71-141. Reinhold Publishing Corp., New York.

Jackson M.L., Clayton R.N., Violante E., Violante P. (1982) Eolian influence on Terra Rossa soils of Italy traced by quartz oxygen isotope ratio. In: Proceedings of the Seventh International Clay Conference (eds. H. van Olphen and F. Veniale): 293-301. Elsevier, Amsterdam.

Jolivet L., Daniel J.M., Fournies M. (1991) Geometry and kinematics of extension in Alpine Corsica. Earth and Planetary Science Letters, 104: 278-291.

Lugli S. (2001) Timing of post-depositional events in the Burano Formation of the Secchia Valley (Upper Triassic, northern Apennines) clues from gypsum-anhydrite transition and carbonate metasomatism. Sedimentary Geology, 140: 107-122.

Lugli S., Morteani G., Dominique B. (2002) Petrographic, REE, fluid inclusion and stable isotope study of magnesite from the Upper Triassic Burano Evaporites (Secchia Valley, northern Apennines): contributions from sedimentary, hydrothermal and metasomatic sources. Mineralium Deposita, 37: 480-494.

Lynch F.L., Mahler B.J., Hauwert N. (2003) Provenance of suspended sediment discharged from a karst aquifer determined by clay mineralogy. In: Studies of Cave Sediments (eds. I.D. Sasowsky and J.E. Mylroie): 83-94. Kluwer Academic, New York.

Martín-García R., Martín-Pérez A., Alonso-Zarza A.M. (2011) Weathering of host rock and corrosion over speleothems in Castañar Cave, Spain: an example of a complex meteoric environment. Carbonates and Evaporites, 26 (1): 83-94.

Martín-Pérez A., Martín-García R., Alonso-Zarza A.M., Herrero M.J. (2010) Features and origin of red clays in Castañar Cave: a touch of colour. In: Advances in Research in Karst Media (eds. B. Andreo, F. Carrasco, J.J. Durán and J.W. LaMoreaux): 515-520. Springer-Verlag, Berlin.

Martini I. (2011) Cave clastic sediments and implications for speleogenesis: new insights from the Mugnano Cave (Montagnola Senese, Northern Apennines, Italy). Geomorphology, 134: 452-460.

Martini I., Aldinucci M., Foresi L.M., Mazzei R., Sandrelli F. (2011) Geological map of the Pliocene succession of the Northern Siena Basin (Tuscany, Italy). Journal of Maps, 2011: 193-205.

Mee A.C., Bestland E.A., Spooner N.A. (2004) Age and origin of terra rossa soils in the Coonawarra area of South Australia. Geomorphology, 58: 1-25.

Merino E., Banerjee A. (2008) Terra rossa genesis, implications for karst, and eolian dust: a geodynamic thread. Journal of Geology, 116: $62-75$.

Millot G. (1970) Geology of Clays. Springer-Verlag, Berlin.

Moore D.M., Reynolds R.C. Jr. (1997) X-Ray Diffraction and the Identification and Analysis of Clay Minerals. Oxford University Press, Oxford.

Moresi M., Mongelli G. (1988) The relation between the terra rossa and the carbonate-free residue of the underlying limestones and dolostones in Apulia, Italy. Clay Minerals, 23: 439-446.

Muhs D.R., Budahn J., Avila A., Skipp G., Freeman J., Patterson D. (2010) The role of African dust in the formation of Quaternary soils on Mallorca, Spain and implications for the genesis of Red Mediterranean soils. Quaternary Science Reviews, 29: 2518-2543.

Pascucci V. (2004) Karst and palaeonvironment of the Siena area (Central Italy). In: 32nd International Geological Conference, 
Florence, Italy (eds. L. Guerrieri, I. Rischia and L. Serva): 20-28.

Passeri L. (1975) L'ambiente deposizionale della formazione evaporitica nel quadro della paleogeografia del Norico Tosco-Umbro-Marchigiano. Bollettino della Società Geologica Italiana, 94: 231-268.

Passeri L. (1979) The hypothesis of a northern Apenninic Peninsula during the upper Triassic. Memorie della Società Geologica Italiana, 20: 151-161.

Petschick R. (2001) MacDiff 4.2.5. http://servermac.geologie.uni-frankfurt.de/Rainer.html

Priori S., Costantini E.A.C., Capezzuoli E., Protano G., Hilgers A., Sauer D., Sandrelli F. (2008) Pedostratigraphy of Terra Rossa and Quaternary geological evolution of a lacustrine limestone plateau in central Italy. Journal of Plant Nutrition and Soil Sciences, 171: 509-523.

Reifenberg A. (1947) The soil of Palestine (2nd ed.). Thomas Murby and Co., London.

Ruhe R.V. (1975) Geomorphology. Houghton-Mifflin, Boston.

Ruhe R.V., Cady J.G., Gomez R.S. (1961) Paleosols of Bermuda. GSA Bulletin, 72: 1121-1142.
Sawhney B.L. (1989) Interstratification in Layer Silicates. In: Minerals in Soil Environments (eds. J.B. Dixon and S.B. Weed): 789-828. Soil Science Society of America, Madison, Wisconsin, USA.

Schaetzl R.J., Anderson S. (2005) Soils: Genesis and Geomorphology. Cambridge University Press, Cambridge.

Signorini R. (1966) I terreni neogenici del Foglio "Siena". Bollettino della Società Geologica Italiana, 85: 639-654.

Tate S.E., Greene R.S.B., Scott K.M., McQueen K.G. (2007) Recognition and characterisation of the aeolian component in soils in the Girilambone Region, north western New South Wales, Australia. Catena, 69: 122-133

Yaalon D.H. (1997) Soils in the Mediterranean region: what makes them different? Catena, 28: 157-169.

Yaalon D.H., Ganor E. (1973) The influence of dust on soils during the Quaternary. Soil Science, 116: 146-155.

Walker G.F. (1949) The decomposition of biotite in the soil. Mineralogical Magazine, 28: 693-703.

Wilson M.J. (1987) X-ray powder diffraction methods. In: A Handbook of Determinative Methods in Clay Mineralogy (ed. M.J. Wilson): 26-98. Blackie, London. 